\title{
PERBANDINGAN HASIL BELAJAR SISWA DENGAN DAN TANPA MENGGUNAKAN ALAT PERAGA DALAM MEMAHAMI KONSEP SEGITIGA DI KELAS VII MTS SITI MARIAM BANJARMASIN TAHUN PELAJARAN 2013/2014
}

\author{
Muhammad Alfhi R \& Rahmawati
}

\begin{abstract}
Abstrak
Taraf berpikir dari siswa MTs baru mulai mampu memahami hal-hal abstrak, maka dalam pengajaran matematika di MTs perlu dibantu suatu alat peraga, sehingga pelajaran menjadi lebih menarik, menjadi konkrit, dan mudah dipahami, serta diharapkan dapat meningkatkan hasil belajar matematika siswa. Penelitian ini bertujuan untuk mengetahui (i) hasil belajar siswa yang diajar menggunakan alat peraga dalam memahami konsep segitiga di kelas VII MTs Siti Mariam tahun pelajaran 2013/2014 (ii) hasil belajar siswa yang diajar tanpa menggunakan alat peraga dalam memahami konsep segitiga di kelas VII MTs Siti Mariam tahun pelajaran 2013/2014. (iii) terdapat perbedaan yang signifikan antara hasil belajar siswa yang diajarkan menggunakan alat peraga dengan hasil belajar siswa tanpa menggunakan alat peraga dalam memahami konsep segitiga di kelas VII MTs Siti Mariam Tahun Pelajaran 2013/2014.

Penelitian ini menggunakan metode eksperimen, dengan populasi seluruh kelas VII MTs Siti Mariam Banjarmasin dan teknik pengambilan sampel menggunakan teknik sampel acak. Sebagai sampel yaitu kelas VIIA berjumlah 37 orang dan kelas VII B berjumlah 37 orang. Teknik pengumpulan data dengan cara tes, dokumentasi, observasi serta wawancara, analisis data dilakukan dengan uji statistik yaitu uji normalitas, uji homogenitas, uji t dan uji $U$.

Hasil penelitian ini menunjukkan hasil belajar siswa di kelas eksperimen mempunyai nilai rata-rata adalah 78,28 dan hasil belajar siswa di kelas control mempunyai nilai rata-rata adalah 72,32. Berdasarkan hasil uji $t$ dimana $t_{\text {hitung }}=2,09$ lebih besar dari $t_{\text {tabel }}=$ 1,968. maka $H_{0}$ ditolak dan $H_{a}$ diterima, sehingga terdapat perbedaan yang signifikan antara hasil belajar siswa kelas eksperimen yang diajarkan dengan menggunakan alat peraga dengan hasil belajar siswa kelas kontrol yang diajarkan tanpa menggunakan alat peraga dalam memahami konsep pada materi segitiga.
\end{abstract}

Kata Kunci: perbandingan, hasil belajar, alat peraga, konsep segitiga 


\section{Pendahuluan}

Peraturan Pemerintah Nomor 19 Tahun 2005 Pasal 42 (1) menyatakan bahwa "Setiap satuan pendidikan wajib memiliki sarana yang meliputi perabot, peralatan pendidikan, media pendidikan, buku dan sumber lainnya, bahan-bahan habis pakai, serta perlengkapan lain yang diperlukan untuk menunjang proses pembelajaran yang teratur dan berkelanjutan".

Objek dalam pembelajaran matematika yang berupa fakta, konsep, prinsip dan skill/keterampilan merupakan benda pikiran yang sifatnya abstrak dan tidak dapat diamati dengan pancaindera. Oleh karena itu wajar apabila pada umumnya matematika tidak mudah dipahami oleh kebanyakan siswa.

Untuk mengatasi hal tersebut, maka dalam mempelajari suatu objek dalam pembelajaran matematika diperlukan pengalaman melalui bendabenda nyata (konkrit) yaitu alat peraga yang dapat digunakan sebagai jembatan bagi siswa untuk berpikir abstrak. Konsep abstrak matematika yang disajikan dalam bentuk konkret akan lebih dapat dipahami dan dimengerti oleh siswa. Diharapkan dengan menggunakan alat peraga siswa dapat melihat, meraba dan mengungkapkan dengan memikirkan secara langsung objek yang sedang mereka pelajari. Sehingga konsep abstrak yang sedang dipelajari dapat mengendap, melekat dan tahan lama dibenak pikiran siswa.

Sebagaimana yang diharapkan dalam KTSP, guru sebagai fasilitator dalam kegiatan belajar mengajar berperan penting untuk menentukan kelancaran proses belajar siswanya. Dengan memilih suatu media yang tepat, guru dapat mengaktifkan siswa dan mengontrol kegiatan belajar mengajar agar berjalan dengan baik. Menurut Syaiful Bahri Djamarah (2006 : 122) proses belajar mengajar dengan media dapat mempertinggi kegiatan belajar anak didik. Dalam dunia pendidikan, seorang guru yang hendak mengajarkan suatu materi kepada muridnya dituntut menggunakan media sebagai alat bantu sampainya materi. Media yang dipergunakan 
Perbandingan Hasil Belajar Siswa Dengan Dan Tanpa Menggunakan Alat Peraga Dalam Memahami Konsep Segitiga Di Kelas VII MTs Siti Mariam Banjarmasin Tahun Pelajaran 2013/2014

tidak harus berupa media yang mahal, melainkan media yang benar-benar efisien dan mampu manjadi alat penghubung antara seorang guru dengan murid agar materi yang diajarkan dapat diterima dan dipahami secara maksimal.

Pembelajaran matematika saat ini sudah cukup lama terbenam dalam pembelajaran matematika yang bagi banyak orang terasa asing, formal, dan hanya bermain angka atau simbol yang sulit dan serba tak berarti, bahkan tidak sedikit yang merasa ketakutan untuk menghadapi pelajaran matematika. Begitu pula dalam pembelajaran pada materi segitiga. Guru di sekolah cenderung langsung memberikan rumus dan bagaimana menggunakan rumus tersebut untuk menyelesaikan soal yang ada, sehingga siswa tidak mengetahui makna dari simbol-simbol yang mereka gunakan. Hal ini membuat pembelajaran matematika menjadi tidak menyenangkan karena hanya diajarkan dengan cara mekanistik.

Sudah saatnya pembelajaran matematika khususnya pada materi segitiga di kemas dalam pembelajaran yang asyik dan menyenangkan. Salah satu pendekatan pembelajaran yang tepat dalam menanamkan konsep dengan cara yang menyenangkan adalah dengan menggunakan media pembelajaran berupa alat peraga.

Hasil penelitian Mahsunah (2012) pada materi perbandingan menyimpulkan bahwa rata-rata hasil belajar matematika yang disampaikan tanpa menggunakan alat peraga adalah 62,58 dan yang menggunakan alat peraga 83,2. Dan hasil belajar matematika siswa kelas IX SMPN 1 Astambul berbeda secara signifikan antara pengajaran menggunakan alat peraga dan tanpa alat peraga.

Hasil penelitian Nurmala Hayati (2010) pada materi simetri lipat dan simetri putar di kelas V MI Haji Hasyim Surabaya menyimpulkan bahwa (1) aktivitas siswa yang paling dominan adalah mengerjakan pertanyaan pada LKS dengan menggunakan alat peraga secara berkelompok, (2) hasil berajar, ketuntasan belajar siswa mencapai $100 \%$ atau semua siswa tuntas 
belajarnya, (3) sebagian besar siswa memberikan respon yang positif terhadap pembelajaranmenggunakan alat peraga.

Berdasarkan pengalaman penulis sendiri ketika observasi sekaligus mengajar matematika saat Praktik Pengalaman Lapangan (PPL) di MTs Siti Mariam Banjarmasin, penulis menemukan berbagai macam masalah mengajar khususnya pada pembelajaran matematika, siswa cenderung kurang memperhatikan penjelasan guru sehingga siswa tidak mengerti dan paham betul pelajaran yang telah diajarkan guru, oleh karenanya penulis mencoba mengajar menggunakan metode yang berbeda dengan guru yaitu dengan menggunakan media pembelajaran, ternyata dengan metode penggunaan media pembelajaran tersebut penulis mampu membuat siswa lebih memperhatikan pelajaran saat dijelaskan.

Bertolak dari uraian di atas, peneliti tertarik untuk mengetahui apakah ada perbedaan hasil belajar matematika antara siswa dalam pengajaran matematika yang menggunakan alat peraga dengan yang tidak. Dalam hal ini peneliti melakukan penelitian di MTs Siti Mariam Banjarmasin, dengan mengambil judul: "Perbandingan Hasil Belajar Siswa dengan dan Tanpa Alat Peraga Kertas dalam Memahami Konsep pada Materi Segitiga di Kelas VII MTs Siti Mariam Banjarmasin Tahun Pelajaran 2013/2014".

\section{Metode Penelitian}

Jenis penelitian yang digunakan pada penelitian ini adalah penelitian lapangan. Penelitian lapangan yaitu penelitian yang dilakukan dengan terjun langsung ke lapangan untuk meneliti penggunaan alat peraga dalam memahami konsep pada materi segitiga di kelas VII MTs Siti Mariam Banjarmasin. Pendekatan dalam penelitian ini menggunakan pendekatan kuantitatif yaitu proses menemukan pengetahuan yang menggunakan data berupa angka sebagai alat mengemukakan keterangan mengenai apa yang kita ketahui (Margono, 2003 : 105). Metode penelitian yang digunakan pada penelitian ini adalah metode penelitian eksperimen. Penelitian ini 
Perbandingan Hasil Belajar Siswa Dengan Dan Tanpa Menggunakan Alat Peraga Dalam Memahami Konsep Segitiga Di Kelas VII MTs Siti Mariam Banjarmasin Tahun Pelajaran 2013/2014

bertujuan untuk menggambarkan ada tidaknya perbedaan hasil belajar siswa antara siswa yang diajar dengan alat peraga dan siswa yang diajar tanpa alat peraga dalam memahami konsep pada materi segitiga di kelas VII MTs Siti Mariam Kelayan A Banjarmasin. Adapun variabel-variabel yang diteliti yaitu variabel bebasnya adalah alat peraga dalam memahami konsep pada materi segitiga di kelas VII, sedangkan variabel terikatnya adalah hasil belajar siswa.

Populasi dalam penelitian ini adalah siswa kelas VII MTs Siti Mariam Kelayan A Banjarmasin Tahun Pelajaran 2013/2014 yang berjumlah 74 siswa yang terdiri dari 37 siswa kelas VII.A dan 37 siswa kelas VII.B. Adapun sampel dari penelitian ini diperoleh dengan menggunakan sampel total yaitu seluruh siswa kelas VII MTs Siti Mariam Kelayan A Banjarmasin dijadikan sebagai sampel penelitian. Sampel dalam penelitian ini dibagi menjadi dua kelompok yaitu kelompok eksperimen dan kelompok kontrol.

Kelompok eksperimen adalah kelompok yang menggunakan alat peraga dalam memahami konsep pada materi segitiga, sedangkan kelompok kontrol adalah kelompok yang tidak menggunakan alat peraga dalam memahami konsep pada materi segitiga. Kelompok yang bertindak sebagai kelompok eksperimen (KE) adalah kelas VIIB dan kelompok yang bertindak sebagai kelas kontrol (KK) adalah kelas VII A yang diambil secara bertujuan atau purposive sampling dalam penentuan mana yang dipilih sebagai kelas eksperimen dan mana yang diambil sebagai kelas kontrol karena sampel pada populasi sudah ditentukan berkelompok yaitu kelas VII A dan Kelas VII B, dimana siswa kelas VII A tidak bisa masuk ke kelas VII B dan sebaliknya.

Teknik pengumpulan data yang digunakan dalam penelitian ini adalah (1) tes prestasi, jenis tes yang digunakan adalah tes tertulis dalam soal bentuk essai. Adapun jumlah soal yang disusun sebanyak 10 soal yang dibagi menjadi dua perangkat soal dan disusun berdasarkan indikatorindikator yang mengacu pada SK/KD MTs kelas VII semester II khususnya pada materi segitiga. Adapun pelaksanaan uji coba instrumen penelitian 
berupa soal-soal dilakukan diluar lokasi penelitian yaitu di MTs Pondok Pesantren Al-Istiqamah Banjarmasin. Hal ini dimaksudkan untuk menghindari terjadinya kebocoran soal, disamping itu MTs Pondok Pesantren Al-Istiqamah Banjarmasin memiliki status yang sama dengan MTs Siti Mariam Banjarmasin yaitu swasta, serta menempati wilayah yang sama yaitu Banjarmasin Selatan dan memiliki KKM matematika yang sama yaitu 73. Uji instrumen tersebut dilakukan pada hari Kamis tanggal 5 Juni2014.

Di sini peneliti, mengambil kelas VIIA yang terdiri dari 20 orang untuk melaksanakan uji coba instrumen perangkat I dan kelas VII B yang juga terdiri dari 20 orang siswa untuk melaksanakan uji coba instrumen II yang dilaksanakan pada hari Kamis tanggal 5 Juni 2014. Uji coba instrumen ini terdiri dari 5 butir soal untuk perangkat I dan 5 butir soal untuk perangkat II.

Berdasarkan hasil uji validitas dan reliabilitas, maka peneliti memilih dari soal perangkat I yang memenuhi kriteria pada uji validitas yang nilai validitasnya tertinggi dan reliabilitas soalnya reliabel adalah soal nomor 1 , 2, 3, dan 4. Sedangkan dari soal perangkat II peneliti memilih soal yang memenuhi kriteria pada uji validitas yang nilai validitasnya tertinggi dan reliabilitas soalnya reliabel adalah soal nomor 5 . Oleh karena itu, soal-soal yang memenuhi kriteria soal baik dan bisa dijadikan instrumen berjumlah 5 soal.

Teknik pengumpulan data selanjutnya adalah (2) Dokumentasi, dokumentasi digunakan untuk mengumpulkan data dalam pelaksanaan pembelajaran matematika dengan alat peraga dalam penanaman konsep pada materi segitiga berupa foto-foto kegiatan serta arsip-arsip sekolah yang dibutuhkan untuk melengkapi data yang diperlukan. (3) Observasi, teknik ini digunakan untuk memperoleh data penunjang tentang deskripsi lokasi penelitian, keadaan siswa, jumlah dewan guru dan staf tata usaha, sarana dan prasarana, serta jadwal belajar. (4) Wawancara, wawancara digunakan untuk melengkapi dan memperkuat data yang diperoleh peneliti dari teknik observasi dan dokumentasi. 
Perbandingan Hasil Belajar Siswa Dengan Dan Tanpa Menggunakan Alat Peraga Dalam Memahami Konsep Segitiga Di Kelas VII MTs Siti Mariam Banjarmasin Tahun Pelajaran 2013/2014

Teknik Analisis Data dalam penelitian ini adalah Data yang diperoleh terdiri dari nilai kognitif hasil belajar matematika siswa di kelas eksperimen dan di kelas kontrol. Data nilai kognitif hasil belajar matematika berupa nilai tes awal dan nilai tes akhir. Data hasil belajar matematika berupa nilai tes kemampuan siswa dan nilai tes akhir yang dianalisis dengan menggunakan statistika deskriptif dan statistik analitik. Statistik analitik yang digunakan adalah uji beda yaitu uji $t$. Sebelum mengadakan uji tersebut terlebih dahulu dilakukan perhitungan statistika yang meliputi rata-rata dan standar deviasi. Uji $t$ digunakan apabila data berdistribusi normal dan homogen.

\section{Rata-Rata}

Menurut Sudjana, untuk menentukan kualifikasi hasil belajar yang dicapai oleh siswa dapat diketahui melalui rata-rata yang dirumuskan dengan:

$$
\bar{x}=\frac{\sum f_{i} x_{i}}{\sum f_{i}}
$$

Keterangan : (Sudjana, $2012: 67$ )

$$
\begin{array}{ll}
\overline{\mathrm{x}} & =\text { nilai rata-rata (mean) } \\
\sum \mathrm{f}_{\mathrm{i}} \mathrm{x}_{\mathrm{i}} & =\text { jumlah hasil perkalian antara masing - masing data dengan } \\
& \text { frekuensinya. } \\
\sum \mathrm{f}_{\mathrm{i}} & =\text { Jumlah data }
\end{array}
$$

\section{Standar Deviasi}

Standar deviasi atau simpangan baku sampel digunakan dalam menghitung nilai $\mathrm{z}_{\mathrm{i}}$ pada uji normalitas.

$$
s=\sqrt{\frac{\sum f_{i}\left(x_{i}-\bar{x}\right)^{2}}{n-1}}
$$

Keterangan : (Sudjana, 2012 :92)

$S=$ Standar deviasi

$\overline{\mathrm{x}} \quad=$ Nilai rata-rata (mean)

$\sum \mathrm{f}_{\mathrm{i}} \quad=$ Jumlah frekuensi data ke-i, yang mana $\mathrm{i}=1,2,3, \ldots$. 


$$
\begin{array}{ll}
\mathrm{n} & =\text { Banyaknya data } \\
\mathrm{x}_{\mathrm{i}} & =\text { Data ke-i, yang mana } \mathrm{i}=1,2,3, \ldots .
\end{array}
$$

\section{Uji Normalitas}

Pengujian normalitas data yang diperoleh dalam penelitian menggunakan uji Liliefors dengan langkah-langkah pengujian sebagai berikut ini. (Sudjana, 2012 : 466)

a. Pengamatan $\mathrm{x}_{1}, \mathrm{x}_{2}, \mathrm{x}_{3}, \ldots, \mathrm{x}_{\mathrm{n}}$ dijadikan bilngan baku $\mathrm{Z}_{1}, \mathrm{Z}_{2}, \mathrm{Z}_{3}, \ldots \mathrm{Z}_{\mathrm{n}}$ dengan menggunakan rumus $Z_{i}=\frac{x_{i}-\bar{x}}{S} \quad(\bar{x}$ dan $S$ masing-masing merupakan rata-rata dan simpangan baku sampel).

b. Untuk tiap bilangan baku ini dan menggunakan daftar distribusi normal baku, kemudian dihitung peluang $\mathrm{F}\left(\mathrm{Z}_{\mathrm{i}}\right)=\mathrm{P}\left(\mathrm{Z} \geq \mathrm{Z}_{\mathrm{i}}\right)$.

c. Selanjutnya dihitung proporsi $\mathrm{Z}_{1}, \mathrm{Z}_{2}, \mathrm{Z}_{3}, \ldots, \mathrm{Z}_{\mathrm{n}} \mathrm{yang}$ lebih kecil atau sama dengan $\mathrm{Z}_{\mathrm{i}}$. Jika proporsi ini dinyatakan oleh $\mathrm{S}\left(\mathrm{Z}_{\mathrm{i}}\right)$, maka:

d. $S\left(Z_{i}\right)=\frac{\text { banyak } Z_{i}, Z_{2}, Z, \ldots Z_{n} \text { yang } \leq Z_{i}}{n}$

e. Hitung selisih $\mathrm{F}\left(\mathrm{Z}_{\mathrm{i}}\right)-\mathrm{S}\left(\mathrm{Z}_{\mathrm{i}}\right)$ kemudian tentukan harga mutlaknya.

f. Ambil harga yang paling besar diantara harga-harga mutlak selisih tersebut, harga ini disebut sebagai $\mathrm{L}_{\text {hitung. }}$

g. Untuk menerima atau menolak hipotesis nol, bandingkan $\mathrm{L}_{\text {hitung }}$ dengan $\mathrm{L}_{\text {tabel }}$ dengan menggunakan tabel nilai kritis uji Liliefors dengan taraf nyata $\alpha=5 \%$ dengan kriteria sebagai berikut:

1) Terima $H_{0}$ jika, $L_{0} \leq L_{\text {tabel }}$

2) Tolak $H_{0}$ jika, $L_{0}>L_{\text {tabel. }}$.

\section{Uji Homogenitas Data}

Setelah data berdistribusi normal, selanjutnya dilakukan uji homogenitas varians. Uji yang digunakan adalah uji varians terbesar dibandingkan varians terkecil menggunakan tabel F. Pada taraf signifikansi yang digunakan adalah $\alpha=5 \%$. 
Perbandingan Hasil Belajar Siswa Dengan Dan Tanpa Menggunakan Alat Peraga Dalam Memahami Konsep Segitiga Di Kelas VII MTs Siti Mariam Banjarmasin Tahun Pelajaran 2013/2014

Hipotesis yang akan diuji sebagai berikut:

$\mathrm{H}_{0}$ : Sampel berasal dari populasi yang variansinya homogen

$\mathrm{H}_{\mathrm{a}}$ : Sampel berasal dari populasi yang variansinya tidak homogen.

Adapun langkah-langkah penyajiannya sebagai berikut:(Riduan, 2005 :120)

a. Menghitung varisans terbesar dan varians terkecil

$$
\mathrm{F}_{\text {hitung }}=\frac{\text { Varians terbesar }}{\text { Varians terkecil }}
$$

b. Membandingkan nilai $\mathrm{F}_{\text {hitung }}$ dengan nilai $\mathrm{F}_{\text {tabel }}$

$\mathrm{db}$ pembilang $=\mathrm{n}-1$ (untuk varians terbesar)

$\mathrm{db}$ penyebut $=\mathrm{n}-1$ (untuk varians terkecil)

Taraf signifikan $(\alpha)=5 \%$

c. Kriteria pengujian

Jika $\mathrm{F}_{\text {hitung }}>\mathrm{F}_{\text {tabel }}$ maka tidak homogen.

Jika $\mathrm{F}_{\text {hitung }} \leq \mathrm{F}_{\text {tabel }}$ maka homogen

\section{Uji Kesamaan Dua Rata-Rata (Uji t)}

Uji perbandingan yaitu uji $t$ dua sampel digunakan untuk membandingkan (membedakan) apakah kedua data (variabel) tersebut sama atau berbeda. Terdapat dua rumus uji t yang dapat digunakan untuk manguji hipotesis komparatif dua sampel independen.

a. Separated Varians:

$$
t^{\prime}=\frac{\overline{x_{1}}-\overline{x_{2}}}{\sqrt{\frac{s_{1}^{2}+s_{2}^{2}}{n_{1}+n_{2}}}}
$$

b. Polled Varians:

$$
t=\frac{\overline{x_{1}}-\overline{x_{2}}}{\sqrt{\frac{\left(n_{1}-1\right) s_{1}^{2}+\left(n_{2}-1\right) s_{2}^{2}}{n_{1}+n_{2}-2}\left(\frac{1}{n_{1}}+\frac{1}{n_{2}}\right)}}
$$

Keterangan: $n_{1}=$ jumlah data pertama (kelas eksperimen)

$$
\begin{aligned}
& n_{2}=\text { jumlah data kedua (kelas kontrol) } \\
& \overline{x_{1}}=\text { nilai rata-rata hitung data pertama }
\end{aligned}
$$




$$
\begin{aligned}
& \overline{x_{2}}=\text { nilai rata-rata hitung data kedua } \\
& {s_{1}}^{2}=\text { varians data pertama } \\
& {s_{2}}^{2}=\text { varians data kedua }
\end{aligned}
$$

Terdapat beberapa pertimbangan dalam memilih rumus uji $t$, yaitu:

a. Apakah dua rata-rata itu berasal dari dua sampel yang jumlahnya sama atau tidak.

b. Apakah varians data dari dua sampel itu homogen atau tidak. Untuk menjawab itu perlu pengujian homogenitas varians.

Berdasarkan dua hal tersebut di atas, maka berikut ini diberikan petunjuk untuk memilih rumus uji t. (Sugiono, 1997 : 138-139)

a. Bila jumlah anggota sampel $\mathrm{n}_{1}=\mathrm{n}_{2}$ dan varians homogen $\left(\mathrm{s}_{1}^{2}=\mathrm{s}_{2}^{2}\right)$, maka dapat digunakan rumus uji $\mathrm{t}$, baik untuk separated maupun polled varians. Untuk mengetahui $\mathrm{t}$ tabel digunakan $\mathrm{dk}$ yang besarnya $\mathrm{dk}=$ $\mathrm{n}_{1}+\mathrm{n}_{2}-2$.

b. Bila $\mathrm{n}_{1} \neq \mathrm{n}_{2}$, varians homogen $\left(\mathrm{s}_{1}^{2}=\mathrm{s}_{2}^{2}\right)$ dapat digunakan uji $\mathrm{t}$ dengan polled varians. Besarnya $\mathrm{dk}=\mathrm{n}_{1}+\mathrm{n}_{2}-2$.

c. Bila $\mathrm{n}_{1}=\mathrm{n}_{2}$, varians tidak homogen $\left(\mathrm{s}_{1}^{2}=\mathrm{s}_{2}^{2}\right)$ dapat digunakan rumus separated maupun polled varians, dengan $\mathrm{dk}=\mathrm{n}_{1}-1$ atau $\mathrm{dk}=\mathrm{n}_{2}-1$.

d. Bila $\mathrm{n}_{1} \neq \mathrm{n}_{2}$ dan varians tidak homogen $\left(\mathrm{s}_{1}^{2}=\mathrm{s}_{2}^{2}\right)$. Untuk ini digunakan rumus separated varians, harga $t$ sebagai pengganti harga $t$ tabel dihitung dari selisih harga $t$ tabel dihitung dari selisih harga $t$ tabel dengan $\mathrm{dk}=\mathrm{n}_{1}-1$ dan $\mathrm{dk}=\mathrm{n}_{2}-1$, dibagi dua dan kemudian ditambah dengan harga t yang terkecil.

Langkah-langkah uji $t$. Adapun langkah-langkah pengujiannya sebagai berikut ini. (Sudjana, 2012 : 239-240)

a. Menghitung nilai rata-rata $\overline{\mathrm{x}}$ dan varians $\left(\mathrm{s}^{2}\right)$ setiap sampel:

$$
\bar{x}=\frac{\sum f_{i} x_{i}}{\sum f_{i}} \operatorname{dans}^{2}=\frac{\sum f_{i}\left(x_{i}-\bar{x}\right)^{2}}{n-1}
$$

b. Menghitung harga t dengan rumus separated variansdan polled varians, 
Perbandingan Hasil Belajar Siswa Dengan Dan Tanpa Menggunakan Alat Peraga Dalam Memahami Konsep Segitiga Di Kelas VII MTs Siti Mariam Banjarmasin Tahun Pelajaran 2013/2014

c. Menentukan nilai $\mathrm{t}$ pada tabel distribusi $\mathrm{t}$ dengan taraf signifikan $\alpha=$ $5 \%$, dengan $d_{k}=\left(n_{1}+n_{2}-2\right)$.

d. Menentukan kriteria pengujian jika $-t_{\text {tabel }} \leq t_{\text {hitung }} \leq t_{\text {tabel }}$ maka $H_{O}$ diterima dan $\mathrm{H}_{\mathrm{a}}$ ditolak.

\section{Hasil Penelitian}

\section{Deskripsi Hasil Belajar Matematika Siswa Pada Tiap Pertemuan}

Hasil belajar siswa pada setiap pertemuan dilihat dari nilai tes formatif yang diberikan pada akhir kegiatan pembelajaran. Data hasil tes formatif yang dilaksanakan siswa pada setiap pertemuan. Secara ringkas, nilai rata-rata hasil tes formatif setiap pertemuan pada kelas kontrol dan kelas eksperimen dapat dilihat pada tabel berikut ini.

Tabel 1. Nilai Rata-Rata Kelas Setiap Pertemuan

\begin{tabular}{|c|c|c|}
\hline \multirow{2}{*}{ Pertemuan Ke- } & \multicolumn{2}{|c|}{ Nilai Rata-Rata } \\
\cline { 2 - 3 } & Kelas Eksperimen & Kelas Kontrol \\
\hline 1 & 88,18 & 80,07 \\
2 & 80,91 & 75,51 \\
3 & 84,55 & 78,38 \\
\hline Rata-Rata & 84,55 & 77,98 \\
\hline
\end{tabular}

Berdasarkan tabel di atas menunjukkan bahwa nilai rata-rata di kelas eksperimen lebih tinggi dari nilai rata-rata kelas kontrol. Selisih nilai rata-rata antara kelas eksperimen dan kelas kontrol adalah 6,57, dimana selisih nilai rata-rata ini didapat dari menjumlahkan nilai ratarata pertemuan ke- 1, 2 dan 3 antara kelas kontrol dengan kelas eksperimen.

\section{Deskripsi Hasil Belajar Matematika Siswa Pada Tes Akhir}

Tes akhir dilakukan untuk mengetahui hasil belajar di kelas eksperimen maupun kelas kontrol. Tes dilakukan pada pertemuan keempat seluruh siswa dapat mengikuti tes akhir. Distribusi jumlah siswa yang mengikuti tes dapat dilihat pada tabel berikut ini : 
Tabel 2. Distribusi Jumlah Siswa yang Mengikuti Tes Akhir

\begin{tabular}{|l|c|c|}
\hline & KE & KK \\
\hline Tes akhir program pengajaran & 37 orang & 37 orang \\
Jumlah siswa seluruhnya & 37 orang & 37 orang \\
\hline
\end{tabular}

Berdasarkan tabel di atas dapat diketahui bahwa pada pelaksanaan tes akhir di kelas eksperimen dan kelas kontrol seluruh siswa dapat hadir untuk mengikuti tes akhir.

3. Deskripsi Hasil Belajar Matematika Siswa Pada Kelas Eksperimen

Hasil belajar matematika siswa kelas eksperimen disajikan dalam tabel berikut ini :

Tabel 3. Distribusi Frekuensi Hasil Belajar Matematika Siswa Kelas Eksperimen

\begin{tabular}{|l|c|c|c|}
\hline \multicolumn{1}{|c|}{ Nilai } & Frekuensi & Persentase (\%) & Keterangan \\
\hline $95,00-100$ & 1 & 2,7 & Istimewa \\
\hline $80,00-<95,00$ & 20 & 54,1 & Amat Baik \\
\hline $65,00-<80,00$ & 8 & 21,6 & Baik \\
\hline $55,00-<65,00$ & 7 & 18,9 & Cukup \\
\hline $40,00-<55,00$ & 1 & 2,7 & Kurang \\
\hline $0-<40,00$ & - & - & Amat Kurang \\
\hline Jumlah & 37 Siswa & $100 \%$ & \\
\hline
\end{tabular}

Berdasarkan tabel di atas dari 37 siswa yang mengikuti pembelajaran ada 1 orang atau 2,7\% yang termasuk kualifikasi istimewa, ada 20 orang atau 54,1\% yang termasuk kualifikasi amat baik, ada 8 orang 21,6\% yang termasuk kualifikasi baik, 7 orang atau 18,9\% termasuk kualifikasi cukup dan 1 orang atau 2,7\% termasuk kualifikasi kurang. Nilai rata-rata keseluruhan adalah 78,28 dan berada pada kualifikasi baik.

\section{Deskripsi Hasil Belajar Matematika Siswa Pada Kelas Kontrol}

Hasil belajar matematika siswa kelas kontrol disajikan dalam tabel berikut ini : 
Perbandingan Hasil Belajar Siswa Dengan Dan Tanpa Menggunakan Alat Peraga Dalam Memahami Konsep Segitiga Di Kelas VII MTs Siti Mariam Banjarmasin Tahun Pelajaran 2013/2014

Tabel 4. Distribusi Frekuensi Hasil Belajar Matematika Siswa Kelas Kontrol

\begin{tabular}{|l|c|c|c|}
\hline \multicolumn{1}{|c|}{ Nilai } & Frekuensi & Persentase (\%) & Keterangan \\
\hline $95,00-100$ & - & - & Istimewa \\
\hline $80,00-<95,00$ & 14 & 37,838 & Amat Baik \\
\hline $65,00-<80,00$ & 14 & 37,838 & Baik \\
\hline $55,00-<65,00$ & 6 & 16,216 & Cukup \\
\hline $40,00-<55,00$ & 3 & 8,108 & Kurang \\
\hline $0-<40,00$ & - & - & Amat Kurang \\
\hline Jumlah & 37 Siswa & $100 \%$ & \\
\hline
\end{tabular}

Berdasarkan tabel di atas dapat diketahui bahwa pada kelas kontrol terdapat 14 siswa atau 37,838\% termasuk kualifikasi amat baik, ada 14 siswa atau 37,838\% termasuk kualifikasi baik, ada 6 siswa atau $16,216 \%$ termasuk kualifikasi cukup, dan ada 3 siswa atau 8,108\% termasuk kualifikasi kurang. Nilai rata-rata keseluruhan adalah 72,32 dan termasuk kualifikasi baik.

\section{Uji Beda Hasil Belajar Matematika Siswa}

Rangkuman hasil belajar siswa dari tes akhir yang diberikan dapat dilihat pada tabel berikut ini :

Tabel 5. Deskripsi Hasil Belajar Siswa

\begin{tabular}{|l|c|c|}
\hline & Kelas eksperimen & Kelas kontrol \\
\hline Nilai tertinggi & 96,30 & 88,88 \\
Nilai terendah & 46,30 & 46,30 \\
Rata-rata & 78,28 & 72,32 \\
Standar deviasi & 12,34 & 12,13 \\
\hline
\end{tabular}

Berdasarkan tabel di atas menunjukkan bahwa nilai rata-rata kelas eksperimen lebih tinggi dari nilai rata-rata kelas kontrol dengan selisih 5,96 .

\section{Uji Normalitas}

Uji normalitas dilakukan untuk mengetahui kenormalan distribusi data yang menggunakan uji Liliefors. 
Tabel 6. Rangkuman Uji Normalitas Hasil Belajar

\begin{tabular}{|l|c|c|c|c|}
\hline \multicolumn{1}{|c|}{ Kelas } & $\mathbf{N}$ & $\mathbf{L}_{\text {hitung }}$ & $\mathrm{L}_{\text {tabel }}$ & Kesimpulan \\
\hline Eksperimen & 37 & 0,120 & 0,145 & Normal \\
\hline Kontrol & 37 & 0,101 & 0,145 & Normal \\
\hline
\end{tabular}

Berdasarkan tabel di atas menunjukkan bahwa, harga $L_{\text {hitung }}$ untuk kelas eksperimen lebih kecil dari $L_{\text {tabel }}$ pada taraf signifikansi $\alpha=5 \%$. Hal ini berarti hasil belajar matematika siswa pada kelas eksperimen adalah berdistribusi normal. Demikian pula, untuk kelas kontrol $\mathrm{L}_{\text {hitung }}$ lebih kecil dari harga $\mathrm{L}_{\text {tabel}}$, artinya hasil belajar matematika siswa pada kelas kontrol adalah berdistribusi normal. Maka dapat dinyatakan bahwa kedua kelas berdistribusi normal.

\section{Uji Homogenitas}

Setelah diketahui data berdistribusi normal, pengujian dapat dilanjutkan dengan uji homogenitas varians. Uji ini bertujuan untuk mengetahui apakah hasil belajar siswa di kelas kontrol dan kelas eksperimen homogen atau tidak.

Tabel 7. Uji Homogenitas Varians Hasil Belajar

\begin{tabular}{|l|c|c|c|l|l|}
\hline Kelas & $\mathbf{N}$ & Varians & $\mathbf{F}_{\text {hitung }}$ & $\mathbf{F}_{\text {tabel }}$ & Kesimpulan \\
\hline Eksperimen & 37 & 152,34 & \multirow{2}{*}{1,04} & \multirow{2}{*}{2,028} & Homogen \\
\cline { 1 - 3 } Kontrol & 37 & 147,05 & & & \\
\hline
\end{tabular}

Berdasarkan tabel di atas diketahui bahwa pada taraf signifikansi $\alpha=5 \%$ didapatkan $\mathrm{F}_{\text {hitung }}$ kurang dari $\mathrm{F}_{\text {tabel. }}$. Hal itu berarti hasil belajar kedua kelas bersifat homogen.

8. Uji t

Data berdistribusi normal dan homogen serta jumlah sampelnya sama, maka uji beda (uji t) yang digunakan adalah Polled Varians. Berdasarkan hasil perhitungan, didapat $t_{\text {hitung }}=2,09$, sedangkan $t_{\text {tabel }}=1,968$ pada taraf signifikansi $\alpha=5 \%$ dengan derajat kebebasan $(d f)=72$. Harga $t_{\text {hitung }}$ lebih besar dari $t_{\text {tabel, }}$ dan lebih besar dari $-t_{\text {tabel }}$ maka $H_{0}$ ditolak dan $H_{a}$ diterima. Jadi, dapat disimpulkan bahwa 
Perbandingan Hasil Belajar Siswa Dengan Dan Tanpa Menggunakan Alat Peraga Dalam Memahami Konsep Segitiga Di Kelas VII MTs Siti Mariam Banjarmasin Tahun Pelajaran 2013/2014

terdapat perbedaan yang signifikan antara hasil belajar siswa di kelas kontrol dengan kelas eksperimen.

\section{Pembahasan}

Berdasarkan hasil pengujian yang telah diuraikan maka terdapat perbedaan yang signifikan antara hasil belajar matematika siswa dengan menggunakan alat peraga dalam memahami konsep pada materi segitiga sederhana di kelas VII MTs Siti Mariam Banjarmasin. Demikian pula dari tiga kali pertemuan yang telah dilaksanakan memperlihatkan perbedaan yang berarti dari kedua jenis perlakuan yang diberikan di atas. Hal tersebut dapat dilihat dari nilai rata-rata yang diperoleh siswa yang dikenai perlakuan pada setiap pertemuan.

Pada pertemuan pertama sekaligus juga digunakan sebagai nilai untuk tes kemampuan awal, kelas eksperimen mendapat nilai rata-rata sebesar 88,18, sedangkan kontrol yang tanpa menggunakan alat peraga dalam pembelajaran mendapat nilai rata-rata lebih kecil yaitu 80,08. Pada pertemuan kedua, kelas eksperimen mendapat nilai rata-rata sebesar 80,91, sedangkan kelas kontrol mendapat nilai rata-rata yang lebih kecil yaitu 75,51. Pada pertemuan ketiga, kelas eksperimen mendapat nilai rata-rata sebesar 84,55 , sedangkan kelas kontrol mendapat nilai rata-rata yang lebih kecil yaitu 78,38.

Kemudian setelah dilakukan tes akhir, hasil tes tersebut menunjukkan bahwa nilai rata-rata kelas eksperimen adalah 78,28 dan nilai rata-rata kelas kontrol adalah 72,32, dari kedua nilai rata-rata tersebut berada pada kualifikasi baik. Dari nilai tersebut terlihat perbedaan, selisihnya 5,96.

Dari uraian di atas, dapat dipahami bahwa pembelajaran matematika dengan alat peraga dapat meningkatkan hasil belajar siswa. Penggunaan alat peraga merupakan salah satu pendekatan yang dapat digunakan guru dalam rangka meningkatkan hasil belajar matematika siswa. 


\section{Kesimpulan}

Berdasarkan penelitian yang telah dilakukan dapat diambil beberapa kesimpulan sebagai berikut:

1. Hasil belajar di kelas eksperimen dengan alat peraga dalam memahami konsep pada materi segitiga di kelas VII B MTs Siti Mariam Banjarmasin nilai rata-rata kelasnya adalah 78,28 dan berada pada kualifikasi baik.

2. Hasil belajar di kelas kontrol tanpa alat peraga dalam memahami konsep pada materi segitiga di kelas VII A MTs Siti Mariam Banjarmasin nilai rata-rata kelasnya adalah 72,32 dan berada pada kualifikasi baik.

3. Berdasarkan hasil uji $t$ dimana $t_{\text {hitung }}=2,09$ lebih besar dari $t_{\text {tabel }}=1,968$. maka $\mathrm{H}_{0}$ ditolak dan $\mathrm{H}_{\mathrm{a}}$ diterima, sehingga terdapat perbedaan yang signifikan antara hasil belajar siswa kelas eksperimen yang diajarkan dengan menggunakan alat peraga dengan hasil belajar siswa kelas kontrol yang diajarkan tanpa menggunakan alat peraga dalam memahami konsep pada materi segitiga.

\section{Daftar Pustaka}

Arifin, Zainal, 2012. Penelitian Pendidikan. Bandung : Rosdakarya Offset.

Arikunto, Suharsimi, 2012. Dasar-Dasar Evaluasi Pendidikan. Jakarta : Bumi Aksara.

Arsyad, Azhar, 2010. Media Pembelajaran. Jakata : Rajagrafindo Persada.

Azwar, Saifuddin, 2005. Metode Penelitian. Yogyakarta : Pustaka Pelajar.

Bahri, Syaiful, Djamarah dan Aswan Zain. 2006. Strategi Belajar Mengajar. Jakarta : Rineka Cipta.

Dahar, Ratna Wilis, 2011. Teori-Teori Belajar dan Pembelajaran. Jakarta : Gelora Aksara Pratama.

Dimyati dan Mudjiono, 1999. Belajar dan Pembelajaran. Jakarta : Rineka Cipta.

Dinas Provinsi Kalimantan Selatan, Pedoman Penyelenggaraan Ujian Akhir Sekolah dan Ujian Akhir Bagi Sekolah/Madrasah Tahun Pelajaran 
Perbandingan Hasil Belajar Siswa Dengan Dan Tanpa Menggunakan Alat Peraga Dalam Memahami Konsep Segitiga Di Kelas VII MTs Siti Mariam Banjarmasin Tahun Pelajaran 2013/2014

2003/2004 Provinsi Kalimantan Selatan. Kalimantan Selatan. Pemerintah Provinsi Kalimantan Selatan, Dinas Pendidikan, 2004.

Gagne, Robert M., 1988. Prinsip-prinsip Belajar untuk Pengajaran. terj. Abdilah Hanafi dan Abdul Manan. Surabaya : Usaha Nasional.

Hamalik, Oemar, 2013. Kurikulum dan Pembelajaran. Jakarta : Remaja Roskdakarya.

Hamalik, Oemar, 2006. Proses Belajar Mengajar. Bandung: Bumi Aksara.

Mahsunah, 2012. "Perbandingan Hasil Belajar Siswa Yang Diajar Dengan dan Tanpa Menggunakan Alat Peraga Pada Konsep Bangun Ruang Sisi Lengkung Siswa Kelas IX SMPN 1 Astambul Tahun Pelajaran 2011/2012”. Skripsi, Banjarmasin, Perpustakaan Pusat IAIN Antasari.

Margono, S., 2003. Metodologi Penelitian Pendidika. Jakarta : Rineka Cipta.

Mulyasa, E., 2003. Kurikulum Berbasis Kompetensi. Bandung : Remaja Rosdakarya.

Nasution, S., 2012. Metode Research (Penelitian Ilmiah). Jakarta : Bumi Aksara.

Nurmala Hayati, "Penerapan Pembelajaran Matematika Model Kooperatif Tipe STAD Dengan Menggunakan Alat Peraga pada Sub Materi Pokok Simetri Lipat dan Simetri Putar di Kelas V MI Haji Hasyim Surabaya”. Skripsi, Surabaya, Perpustakaan Digital UIN Sunan Ampel, 2010.

Ramli, Muhammad, 2010. Media dan Teknolgi Pembelajaran. Banjarmasin.

Riduan, 2005. Belajar Mudah Penelitian untuk Guru-Karyawan dan Peneliti Pemula. Bandung : Alfabeta.

Russefendi, 2006. Pengantar kepada Membantu Guru Mengembangkan Kompetensinya dalam Pengajaran Matematika untuk Meningkatkan CBSA. Bandung : Tarsito.

Sardiman, 2008. Interaksi dan Motivasi Belajar-Mengajar. Jakarta : Raja Grafindo Persada.

Simanjuntak, Lisnawati, dkk., 1993. Metode Mengajar Matematika (jilid I). Jakarta : Rineka Cipta. 
Sitanggang, Ahmading, Alat Peraga Matematika Sederhana Untuk Sekolah Dasar.http://lpmp-sumut.or.id/1/wpcontent/uploads/2013/04/ALATPERAGA-SEDERHANA.pdf

Sudjana, Nana, 2012. Metode Statistika. Bandung : Tarsito.

Sudjana, Nana, 2006. Penilaian Hasil Proses Belajar Mengajar. Bandung : Remaja Rosdakarya.

Sudjana, Nana, 2002. Dasar-dasar Proses Belajar Mengajar. Bandung : Sinar Baru Algensindo.

Sugiyono, 2011. Metodologi Penelitian Pendidikan (Pendekatan Kuantitatif, Kualitatif, dan $R \& D$ ). Bandung : Alfabeta.

Usman dan Setiawati, 2001. Upaya Optimalisasi Kegiatan Belajar Mengajar. Bandung : Remaja Rosda Karya.

Warsita, Bambang, Teknologi Pembelajaran: Landasan dan Aplikasinya. Jakarta, Rineka Cipta, 2008.

Muhammad Alfhi Risyandi

Mahasiswa Prodi PMTK, IAIN Antasari Banjarmasin

E-mail: -

\section{Rahmawati}

Dosen Prodi PMTK, IAIN Antasari Banjarmasin

E-mail: palimbangan_math@yahoo.com 